\title{
PENGARUH PENGHINDARAN PAJAK TERHADAP BIAYA HUTANG DAN KEPEMILIKAN INSTITUSIONAL SEBAGAI PEMODERASI
}

\author{
FAHREZA UTAMA \\ DWI JAYA KIRANA \\ KORNEL SITANGGANG \\ Universitas Pembangunan Nasional Veteran Jakarta, Jalan RS. Fatmawati No.1 - Pondok Labu, Jakarta 12450, \\ Indonesia \\ fahreza25.fu@gmail.com
}

\begin{abstract}
The aim of this study is to test the influence of tax avoidance towards the cost of debt moderated by institutional ownership. In this research, tax avoidance measured by proxy of Book Tax Different (BTD) and Cash Effective Tax Rate (CETR). The population in this research is manufacturing firms that listed on Indonesia Stock Exchange (IDX) with 2015-2017 time periods. The amount of sample before outlier is 198 datas collected with purposive sampling method, then the amount of sample after outlier is 187 datas for first model and 186 datas for second model. Cross section data is used in this research. Multiple linear regression, determination coefficients, and partial test (t-test) is used with some help of programming data using SPSS (Statistical Product and Service Solution) 23th version to analize in this research. The result of this study indicate tax avoidance has not significant influence towards the cost of debt, and institutional ownership can't moderate the relationship between tax avoidance and the cost of debt.
\end{abstract}

Keywords: Tax avoidance, cost of debt, institutional ownership, effective tax rate

Abstrak: Tujuan dari penelitian ini adalah untuk menguji pengaruh penghindaran pajak terhadap biaya hutang yang dimoderasi oleh kepemilikan institusional. Dalam penelitian ini, penghindaran pajak diukur dengan proksi Buku Pajak Berbeda (BTD) dan Tarif Pajak Efektif Tunai (CETR). Populasi dalam penelitian ini adalah perusahaan manufaktur yang terdaftar di Bursa Efek Indonesia (BEI) dengan periode 2015-2017. Jumlah sampel sebelum outlier adalah 198 data yang dikumpulkan dengan metode purposive sampling, kemudian jumlah sampel setelah outlier adalah 187 data untuk model pertama dan 186 data untuk model kedua. Data cross section digunakan dalam penelitian ini. Regresi linier berganda, koefisien determinasi, dan uji parsial (uji-t) digunakan dengan bantuan pemrograman data menggunakan SPSS (Solusi Produk dan Layanan Statistik) versi ke-23 untuk dianalisis dalam penelitian ini. Hasil penelitian ini menunjukkan penghindaran pajak tidak berpengaruh signifikan terhadap biaya hutang, dan kepemilikan institusional tidak dapat memoderasi hubungan antara penghindaran pajak dan biaya hutang.

Kata kunci: Penghidaran pajak, biaya hutang, kepemilikan institusional, tarif pajak efektif

\section{PENDAHULUAN}

Indonesia merupakan negara yang pergerakan ekonominya disokong oleh penerimaan dari pajak, karena pajak merupakan penerimaan dengan proporsi terbesar dibandingkan dengan penerimaan lainnya. Setiap tahunnya pun pendapatan dari pajak 
selalu menjadi pendapatan terbesar dibandingkan dengan pendapatan lainnya. Anggaran pendapatan dan belanja negara (APBN) tahun 2015-2017 yang diakses melalui kemenkeu.go.id menunjukkan bahwa penerimaan dari pajak sebesar Rp1.201,7 triliun atau sebesar 67\% pada APBN 2015, dan sebesar Rp1.546,7 triliun atau sebesar 84,8\% pada APBN 2016, serta sebesar Rp1.498,9 triliun atau sebesar 85,75\% pada APBN 2017.
Pemerintah Indonesia perlu untuk selalu memperbaharui, memperbaiki, dan menyempurnakan peraturan perpajakan dan menaikkan target penerimaan pajak setiap tahunnya demi kemakmuran rakyat dan demi menjaga kestabilan penerimaan negara. Berikut target penerimaan pajak beserta realisasinya dari tahun 2013-2017 yang dapat tercermin dari tabel dibawah:

Tabel 1 Persentase Capaian Penerimaan Pajak di Indonesia

(dalam triliun rupiah)

\begin{tabular}{llllll}
\hline \multicolumn{1}{c}{ Tahun } & \multicolumn{1}{c}{2013} & \multicolumn{1}{c}{2014} & \multicolumn{1}{c}{2015} & \multicolumn{1}{c}{2016} & \multicolumn{1}{c}{2017} \\
\hline Target & 995,21 & $1.072,32$ & $1.294,26$ & $1.355,20$ & $1.283,56$ \\
Realisasi & 921,27 & 981,83 & $1.060,83$ & $1.105,81$ & $1.151,13$ \\
Capaian & $92,57 \%$ & $91,56 \%$ & $81,96 \%$ & $81,60 \%$ & $89,68 \%$ \\
\hline
\end{tabular}

Sumber: Laporan Kinerja Direktorat Jendral Pajak Tahun 2016 dan 2017

Perusahaan merupakan wajib pajak badan yang melakukan pembayaran dan penyetoran PPh pasal 25/29 badan, namun perusahaan juga masih menganggap bahwa pajak merupakan beban yang cukup besar yang akan mengurangi laba yang diharapkan perusahaan yaitu laba setelah pajak. Untuk menjaga stabilitas laba yang diharapkan biasanya perusahaan akan mengupayakan beberapa cara melalui manajemen perpajakan salah satunya dengan melakukan perencanaan pajak (tax planning). Perencanaan pajak dapat berupa penyelundupan pajak (tax evasion) dan penghindaran pajak (tax avoidance). Menurut Puspita dan Febrianti (2017), penggelapan pajak (tax evasion) merupakan tindakan yang dilakukan oleh perusahaan untuk mengurangi pajak dengan melanggar peraturan pajak yang berlaku, sedangkan penghindaran pajak (tax avoidance) merupakan tindakan penghindaran pajak secara legal dengan tidak melanggar peraturan perpajakan untuk meminimalkan beban pajak dengan memanfaatkan kelemahan dalam undang-undang perpajakan. Perencanaan Pajak (Tax Planning) perusahaan dapat memanfaatkan peraturan mengenai beban yang dapat dibebankan pada penghasilan sehingga perusahaan dapat mengelola kebijakan pendanaannya. Pendanaan bagi perusahaan bisa didapat dari internal berupa penjualan saham sendiri dan dari eksternal perusahaan berupa hutang. Ada dua jenis biaya yang timbul akibat kegiatan pendanaan, jenis biaya tersebut adalah cost of debt dan cost of equity. Peraturan perpajakan mempunyai perlakuan yang berbeda terhadap kedua biaya tersebut, pada cost of equity seperti dividen tidak dapat dibebankan pada penghasilan karena dividen merupakan pengurang dari cadangan laba yang ditahan bukan pengurang dari laba/rugi, sedangkan cost of debt seperti biaya/beban bunga dapat dibebankan pada penghasilan atau dapat mengurangi penghasilan yang berdampak pada menurunnya pajak yang harus dibayarkan oleh perusahaan.

Hutang merupakan salah satu alternatif dalam melakukan pendanaan. Menurut peraturan yang ada besarnya perbandingan antara hutang dan modal ditetapkan paling tinggi sebesar empat dibanding satu (4:1) yang tercantum dalam peraturan menteri keuangan Republik Indonesia Nomor 169/PMK.010/2015 pasal 2 ayat (1). Menurut Meiriasari (2017), 
hutang pada umumnya digunakan sebagai salah satu alternatif pendanaan bagi perusahaan karena memberikan manfaat berupa penghematan pajak (tax savings), dimana beban bunga pinjaman bersifat mengurangi besarnya pajak yang harus dibayarkan oleh perusahaan (tax deductible).

Penelitian yang dilakukan Santosa dan Kurniawan (2016) dan penelitian dari Masri dan Martani (2014) menyatakan bahwa penghindaran pajak dan biaya hutang memiliki pengaruh positif, dimana penghindaran pajak dapat menciptakan risiko dengan cara menambah biaya hutang. Penelitian mengenai pengaruh moderasi kepemilikan institusional terhadap hubungan penghindaran pajak dan biaya hutang yang dilakukan Lim (2011) menyatakan kepemilikan institusional dapat memoderasi pengaruh penghindaran pajak terhadap biaya hutang.

\section{Teori Keagenan}

Ross et al. (2016 menjelaskan bahwa hubungan yang terjadi antara pemegang saham dan manajemen disebut agency relationship dimana pemegang saham sebagai (principal) mempekerjakan orang lain sebagai (agent) yang bertindak untuk mewakili kepentingannya. Seperti setiap hubungan, ada kemungkinan konflik kepentingan yang mungkin terjadi antara principal dan agent yang disebut dengan agency problem. Menurut Scott (2012) Teori keagenan juga menimbulkan masalah/konflik. Terdapat dua kontrak utama yaitu employment contracts antara pihak internal perusahaan, dan lending contracts antara perusahaan dan pemberi pinjaman. Kedua tipe kontrak ini terjadi bergantung pada penghasilan bersih yang dilaporkan oleh perusahaan. Employment contracts didasarkan pada bonus managerial yang berasal dari laba bersih, dan lending contracts biasanya memberikan perlindungan kepada kreditor dalam bentuk perjanjian yang mengharuskan perusahaan untuk tidak melebihi batas rasio hutang terhadap ekuitas, atau dengan tidak membayarkan dividen apabila modal kerja lebih rendah dari tingkatan tertentu.

Masri dan Martani (2014) berpendapat bahwa tindakan penghindaran pajak itu dipengaruhi oleh agency problem. Dimana terdapat perbedaan kepentingan antara para pihak, di satu sisi manajer menginginkan adanya peningkatan kompensasi, sedangkan pemegang saham ingin menekan biaya pajak, dan kreditor menginginkan perusahaan dapat memenuhi kontrak utang dengan membayar bunga dan pokok pinjaman tepat waktu. Ketika perusahaan memiliki hutang, konflik kepentingan timbul antara pemegang saham dan pemberi pinjaman, dimana konflik ini dapat menjadi lebih besar saat financial distress terjadi dan mempengaruhi agency cost perusahaan (Ross et al. 2002).

Menurut Astuti dan Aryani (2016) adanya perbedaan pelaporan antara laba komersil dan laba fiskal dapat menimbulkan konflik kepentingan (agency problem). Pihak manajer yang bertindak sebagai agent akan melaporkan laba yang lebih tinggi di dalam laporan keuangan komersial agar bisa mendapatkan kompensasi atau bonus, terkait dengan peraturan-peraturan kontrak hutang (debt convenant). Di dalam agency theory, perencanaan pajak dapat memfasilitasi managerial rent extraction yaitu pembenaran atas perilaku oportunistik manajer untuk melakukan manipulasi laba atau penempatan sumber daya yang tidak sesuai. Salah satu dari aktivitas perencanaan pajak adalah penghindaran pajak yaitu tindakan yang dilakukan untuk mengurangi pajak secara legal dengan tidak melanggar peraturan perpajakan untuk meminimalkan beban pajak dengan memanfaatkan kelemahan dalam undangundang perpajakan. Aktivitas penghindaran pajak mendatangkan kesempatan bagi manajemen dalam melakukan aktivitas yang di desain untuk menutupi hal-hal buruk yang dapat menyesatkan investor sehingga dapat dikatakan manajer kurang transparan dalam menjalankan operasional perusahaan. 
Penghindaran pajak dinilai sebagai tindakan manajemen yang kurang transparan yang dapat menimbulkan masalah keagenan. Agency cost pun muncul dikarenakan tindakan penghindaran pajak ini dipengaruhi oleh agency problem. Menurut Kholbaladov (2012) Kepemilikan institusional memiliki dorongan lebih dan kemampuan untuk mengawasi kinerja manajemen. Lim (2011) menyatakan kepemilikan institusional akan mengurangi biaya hutang dengan cara mengurangi agency cost.

\section{Biaya Hutang}

Menurut Ross et al (2016, hlm.3) struktur pendanaan perusahaan merupakan bauran atau pencampuran dari hutang jangka panjang dan ekuitas yang digunakan oleh perusahaan untuk mendanai kegiatan operasi. Sehingga dapat dikatakan bahwa perusahaan memiliki beberapa alternatif dalam melakukan pendanaan yaitu melalui penerbitan saham kepada calon investor atau dengan melakukan pinjaman kepada calon kreditor. Dana yang diberikan dari kreditor berupa pinjaman kepada perusahaan menimbulkan biaya hutang bagi perusahaan (Ashkhabi dan Agustina 2015).

Biaya hutang menurut Ross et al. (2016, hlm.489) merupakan pengembalian yang diharapkan oleh pemberi pinjaman perusahaan atas pinjaman baru, atau secara sederhana biaya hutang adalah tingkat bunga yang harus dibayarkan oleh perusahaan atas pinjaman baru. Pittman dan Fortin (2004) mengukur biaya hutang dari beban bunga yang dibayarkan perusahaan dalam 1 periode dibagi dengan jumlah rata-rata pinjaman jangka pendek dan panjang yang menghasilkan bunga pada periode tersebut.

\section{Penghindaran Pajak}

Penghindaran pajak merupakan cara yang digunakan oleh perusahaan untuk meminimalkan pajak yang terutang dengan cara yang legal melalui pemanfaatan celah-celah hukum, keambiguan, anomali, dan pengertian lainnya dari hukum pajak (Lyons 1996) dalam
(Suandy E, 2011 hlm.7). Menurut Mardiasmo (2016, hlm.11), penghindaran pajak adalah usaha untuk mengurangi beban pajak dengan tidak melanggar peraturan yang ada. Penghindaran pajak (tax avoidance) ini secara sederhana dapat diartikan sebagai usaha yang dilakukan oleh perusahaan untuk mengoptimalkan laba setelah pajak dengan cara yang legal dengan memanfaatkan kelemahan peraturan yang ada salah satunya dengan meminimalisasi beban pajak.

Penghindaraan pajak dapat diukur dengan beberapa pengukuran. Penghindaran pajak diukur melalui BTD untuk melihat ketaatan perusahaan terhadap peraturan perpajakan. Menurut Desai dan Dharmapala (2006) di dalam Kholbaladov (2012) BTD tidak dapat merefleksikan penghindaran pajak perusahaan. Oleh karena itu Cash ETR akan digunakan sebagai pembanding karena kas yang dibayarkan oleh perusahaan dapat mencerminkan tindakan penghindaran pajak, dimana hal ini disebabkan kas yang dibayarkan oleh perusahaan untuk pajak merupakan beban pajak yang telah terealisasi pembayarannya.

\section{Kepemilikan Institusional}

Menurut Juniarti dan Sentosa (2009), kepemilikan institusional adalah kepemilikan saham perusahaan yang dimiliki oleh investor institusional, investor institusional yang dimaksud ialah perusahaan investasi, bank, perusahaan asuransi, institusi luar negeri, dana perwalian serta institusi lainnya. Dan menurut Brancato (1997) dalam Murtianingsih (2014) investor institusional mengacu pada investor yang memiliki manajemen professional yang melakukan investasi atas nama pihak lain, baik sekelompok individu maupun sekelompok organisasi. Tingkatan dari kepemilikan institusional adalah ukuran utama dari kualitas aktivitas pemegang saham (Desai dan Dharmapala, 2009) dalam (Kholbaladov, 2012). Salah satu aktivitas yang dilakukan oleh pemegang saham adalah melakukan pengawasan terhadap manajemen. Kepemilikan 
saham oleh investor institusional dinilai mempunyai kemampuan yang lebih untuk melakukan pengawasan secara optimal terhadap kinerja manajemen. Sehingga semakin tinggi tingkat kepemilikan institusional maka semakin tinggi juga tingkat pengawasan terhadap manajemen. Menurut Meiriasari (2017) pada umumnya kepemilikan institusional memiliki proporsi kepemilikan dalam jumlah yang besar yang menyebabkan proses pengawasan terhadap manajemen menjadi lebih baik.

Jensen dan Meckling (1976) menyatakan bahwa kepemilikan institusional merupakan salah satu mekanisme corporate governance yang dapat digunakan dalam mengendalikan agency problem. Juniarti dan
Sentosa (2009) menegaskan bahwa kepemilikan institusional merupakan perwujudan dari prinsip GCG. Menurut Ashbaugh et al (2004) adanya kepemilikan saham oleh investor institusional akan mendorong peningkatan pengawasan yang lebih optimal terhadap kinerja manajemen karena mereka memiliki voting power untuk mengadakan perubahan pada saat manajemen sudah dianggap tidak efektif lagi dalam mengelola perusahaan. Kepemilikan institusional adalah kepemilikan saham perusahaan oleh investor institusional yang mempunyai manajemen yang baik dan profesional yang menanamkan saham atas nama sekelompok individu ataupun sekelompok organisasi.

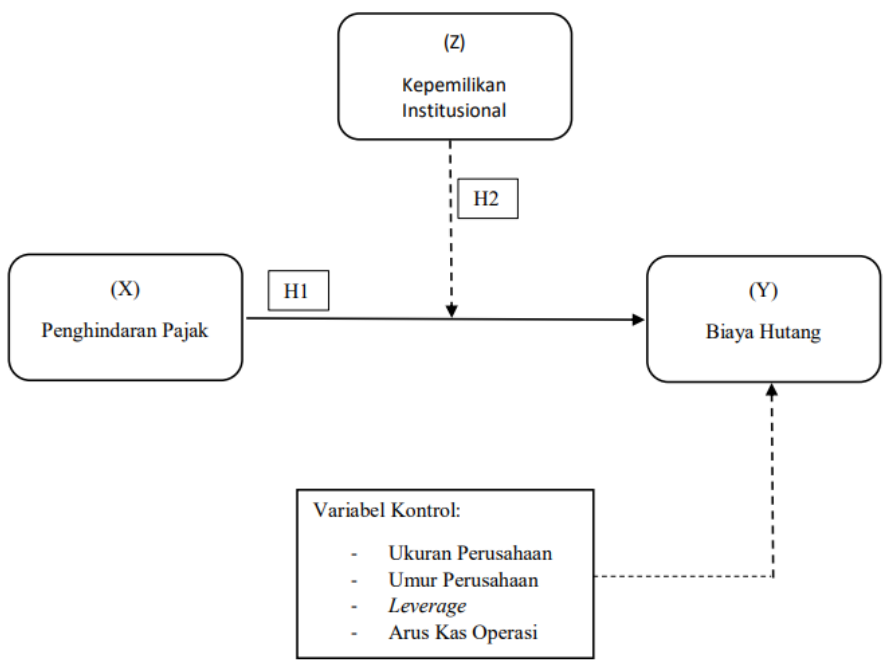

\section{Gambar 1 Model Penelitian}

\section{Pengaruh Penghindaran Pajak terhadap Biaya Hutang}

Perusahaan memiliki beberapa alternatif dalam pendanaan salah satunya melalui hutang. Teori keagenan menjelaskan bahwa ketika perusahaan memiliki hutang maka akan timbul konflik kepentingan, dimana pemegang saham dan pemberi pinjaman berperan sebagai (principal) dan manajemen berperan sebagai (agent).
Pemegang saham menginginkan kinerja yang baik dari perusahaan sehingga akan menaikkan nilai dari perusahaan, pemberi pinjaman mengharapkan pengembalian berupa bunga yang baik dan tinggi dari dana yang dipinjamkan, dan manajemen menginginkan kompensasi (bonus) yang tinggi atas kinerjanya. Perilaku penghindaraan pajak merupakan upaya yang dilakukan oleh perusahaan untuk meminimalisasi pembayaran pajak dengan 
menggunakan hutang, dan secara hukum diperbolehkan. Di dalam pengelolaan sumber pendanaan perusahaan memiliki berbagai alternatif, salah satunya melakukan pinjaman dari kreditor. Perusahaan yang menggunakan hutang dinilai memiliki nilai yang lebih tinggi dibandingkan dengan perusahaan yang tidak menggunakan hutang. Hutang akan mendatangkan biaya hutang yang dapat digunakan sebagai tax shield berupa pengurangan pajak yang akan berdampak pada peningkatan nilai perusahaan. Di sisi lain penggunaan hutang ini mendatangkan risiko bagi perusahaan, dan ukuran dari biaya hutang ini merupakan informasi sebagai indikasi adanya risiko. Perusahaan yang melakukan penghindaran pajak dipandang sebagai kreditor sebagai tindakan yang berisiko sehingga akan meningkatkan biaya hutang dari perusahaan.

H1: Penghindaraan pajak berpengaruh positif terhadap biaya hutang.

\section{Pengaruh Penghindaran Pajak terhadap Biaya Hutang dan Kepemilikan Institusional sebagai Pemoderasi}

Tindakan penghindaran pajak menyebabkan agency problem dan konflik kepentingan antara pemegang saham, pemberi pinjaman, dan manajemen. Sehingga diperlukannya mekanisme corporate governance oleh perusahaan. Kepemilikan institusional merupakan salah satu mekanisme corporate governance yang dapat digunakan dalam mengendalikan agency problem. Kepemilikan institusional dipercaya memiliki kemampuan yang lebih baik dalam mengawasi kinerja dari manajemen, sehingga pengawasan yang optimal dapat tercipta dan nilai perusahaan menjadi lebih baik.

Tingkatan dari kepemilikan institusional merupakan ukuran utama dari kualiatas aktivitas pemegang saham. Semakin tinggi kepemilikan institusional maka semakin besar pengawasan pemegang saham terhadap kinerja manajemen yang dapat mengurangi agency problem, sehingga dapat mengurani konflik antara manajemen dan kreditor. Kepemilikan institusional akan mengurangi biaya hutang dengan cara mengurangi agency cost, yang berdampak mengurangi peluang terjadinya penghindaran pajak. Tindakan penghindaran pajak dilakukan untuk mengoptimalisasi laba setelah pajak dengan meminimalisasi pembayaran pajak. Kepemilikan institusional dipercaya dapat meningkatkan kinerja perusahaan karena memiliki kemampuan pengawasan yang lebih optimal terhadap manajemen.

H2: Kepemilikan institusional memoderasi penghindaran pajak terhadap biaya hutang.

\section{METODA}

Populasi dalam penelitian ini adalah industri pengolahan (perusahaan manufaktur) yang terdaftar di Bursa Efek Indonesia pada tahun 2015-2017. Perusahaan manufaktur dipilih karena pembayaran atas pajak penghasilan pasal 29 badan di dominasi oleh perusahaan manufaktur dan data tersedia cukup banyak. Kriteria dalam penelitian ini disajikan sebagai berikut:

1. Perusahaan manufaktur yang terdaftar di Bursa Efek Indonesia yang laporan keuangannya telah di audit selama periode 2015-2017.

2. Laporan keuangan memiliki tanggal pelaporan 31 Desember.

3. Laporan keuangan yang memiliki beban pajak kini.

4. Laporan keuangan memiliki beban bunga.

5. Laporan keuangan perusahaan melaporkan jumlah pajak yang dibayarkan pada arus kas operasi.

6. Kepemilikan institusional diatas $20 \%$.

7. Data-data disajikan lengkap selama 3 tahun berturut-turut.

Biaya hutang diukur dari beban bunga yang dibayarkan perusahaan dalam 1 periode dibagi dengan jumlah rata-rata pinjaman jangka pendek dan panjang yang menghasilkan bunga 
pada periode tersebut (Masri dan Martani 2014). Pada penelitian ini penghindaran pajak akan dihitung dengan proksi BTD sesuai dengan penelitian Kholbaladov (2012) yang merupakan selisih dari laba komersial dan laba fiskal, dimana laba fiskal diestimasi menggunakan pajak kini dibagi dengan tariff pajak yang berlaku. Penghindaran pajak juga akan diukur dengan Cash ETR sesuai dengan penelitian dari Astuti dan Aryani (2016) yaitu jumlah pajak yang dibayarkan dengan kas dibagi dengan laba sebelum pajak. Kepemilikan Institusional dapat dihitung melalui persentase kepemilikan saham oleh Investor Institusional sesuai dengan penelitian dari Kholbaladov (2012) yaitu jumlah saham yang dimiliki investor institusional dibagi dengan saham beredar.

Ukuran perusahaanmerupakan skala yang digunakan untuk menggambarkan besar kecilnya suatu perusahaan melalui jumlah aset, jumlah penjualan, rata-rata jumlah penjualan, dan rata-rata jumlah aset. Umumnya perusahaan dapat dibedakan menjadi 3 kategori ukuran yaitu perusahaan besar, perusahaan sedang, dan perusahaan kecil (Puspita dan Febrianti, 2017). Ukuran perusahaan dihitung dari logaritma natura total aset. Umur Perusahaan merupakan ukuran seberapa lama sejak perusahaan menjadi perusahaan terbuka (Lim 2011) atau dengan kata lain sejak kapan perusahaan melakukan IPO (penawaran perdana saham ke publik). Umur perusahaan dapat dihitung dengan mengkurangkan tahun sampel dengan tahun saat melakukan IPO sesuai dengan penelitian dari Lim (2011). Purwanti (2014) mendefinisikan leverage merupakan rasio perhitungan yang digunakan untuk melihat seberapa besar aset yang didanai oleh hutang dan melihat nilai aset yang dipergunakan untuk menjamin hutang perusahaan, sehingga dapat dilakukan analisa terhadap kemampuan perusahaan dalam memenuhi kewajibannya. Leverage dihitung melalui rasio DTA (Debt to Assets) dimana total hutang akan di bagi dengan total aset sesuai dengan penelitian dari Purwanti (2014). Purwanti (2014) mendefinisikan arus kas operasi merupakan aliran kas masuk dan aliran kas keluar dari perusahaan, dimana jika profitabilitas perusahaan rendah maka perusahaan akan menggunakan hutang untuk biaya operasional. Sesuai dengan Kholbadalov (2012) arus kas operasi akan dihitung dengan membagi arus kas operasi dengan total aset sesuai dengan penelitian dari Purwanti (2014).

Model regresi yang digunakan dalam penelitian ini dinyatakan dalam persamaan berikut:

Model 1: Pengaruh BTD terhadap COD dan KI sebagai Pemoderasi

$C O D=\alpha+\beta 1 T A 1+\beta 2$ TA1 ${ }^{*} \mathrm{KI}+\beta 3$ SIZE $+\beta 4$ Age

$+\beta 5 \mathrm{LEV}+\beta 6 \mathrm{CFO}+\mathrm{e}$

Model 2: Pengaruh Cash ETR terhadap COD dan $\mathrm{KI}$ sebagai Pemoderasi

$\mathrm{COD}=\alpha+\beta 1 \mathrm{TA} 2+\beta 2 \mathrm{TA} 2^{*} \mathrm{KI}+\beta 3 \mathrm{SIZE}+\beta 4$ Age

$+\beta 5 \mathrm{LEV}+\beta 6 \mathrm{CFO}+\mathrm{e}$

Keterangan:

a : Konstanta,

$\beta \quad$ : Koefisien

COD : Cost of Debt/biaya hutang,

TA1 : Tax Avoidance/penghindaran pajak (pengukuran BTD),

TA2 : Tax Avoidance/penghindaran pajak (pengukuran Cash ETR),

KI : Kepemilikan Institusional,

AGE : Umur perusahaan,

LEV : Leverage (pengukuran rasio DTA),

CFO : Cash flow operation (arus kas operasi).

e : Error

HASIL DAN PEMBAHASAN 
Tabel 1 Statistik Deskriptif

\begin{tabular}{llllll}
\hline Variabel & N & \multicolumn{1}{c}{ Minimum } & \multicolumn{1}{c}{ Maksimum } & \multicolumn{1}{c}{ Rerata } & \multicolumn{1}{c}{$\begin{array}{l}\text { Deviasi } \\
\text { Standar }\end{array}$} \\
\hline COD & 198 & .0198 & 1.1548 & .189345 & .1347594 \\
TA1 & 198 & $-4976256555^{*}$ & $4392000000^{*}$ & $-89482480^{*}$ & $795533105^{*}$ \\
TA2 & 198 & -39.2170 & 31.7840 & .414665 & 3.9696836 \\
TA1*KI & 198 & $-3981005244^{*}$ & $2201042379^{*}$ & $-76977511^{*}$ & $557119465^{\star}$ \\
TA2*KI & 198 & -30.9862 & 10.6840 & .196801 & 2.6220126 \\
SIZE & 198 & 25.6199 & 33.3202 & 28.889530 & 1.6493427 \\
AGE & 198 & 1.0000 & 37.0000 & 20.000000 & 8.6997287 \\
LEV & 198 & .0941 & 5.0733 & .519133 & .5923981 \\
CFO & 198 & -.1209 & .8839 & .078292 & .1011008 \\
\hline
\end{tabular}

Catatan: *(dalam ribuan dan decimal dihilangkan)

Sumber: Data diolah

Biaya hutang, hasilnya memiliki nilai minimum sebesar 0,0198 yang dimiliki oleh PT.TIFICO FIBER INDONESIA Tbk (TFCO) pada tahun 2017 dan nilai maksimum sebesar 1,1548 yang dimiliki oleh PT.ASTRA OTOPARTS Tbk (AUTO) pada tahun 2016. Rata-rata biaya hutang sampel secara keseluruhan sebesar 0,189345 yang berarti rata-rata perusahaan manufaktur dalam penelitian ini memiliki 18,93\% beban bunga yang ditanggung dari pinjaman jangka pendek dan jangka panjang Variabel bebas yaitu penghindaran pajak yang dihitung dengan pengukuran model 1 , hasilnya nilai minimum sebesar -4.976.256.555.000,0000 yang dimiliki oleh PT.KRAKATAU STEEL (PERSERO) Tbk (KRAS) pada tahun 2015 yang berarti laba komersial lebih kecil dari laba fiskal dan nilai maksimum sebesar 4.392.000.000.000,0000 yang dimiliki oleh PT.ASTRA INTERNATIONAL Tbk (ASII) pada tahun 2017 yang berarti laba komersial lebih besar dari laba fiskal. Rata-rata penghindaran pajak sampel secara keseluruhan sebesar -89.482.480.395,065630 yang berarti rata-rata perusahaan manufaktur dalam penelitian ini memiliki laba komersial yang lebih kecil jika dibandingkan dengan laba fiskalnya.

Penghindaran pajak yang dihitung dengan pengukuran model 2 , hasilnya nilai minimum sebesar $-39,2170$ yang dimiliki oleh PT.UNGGUL INDAH CAHAYA Tbk (UNIC) pada tahun 2015 dan nilai maksimum sebesar 31,7840 yang dimiliki oleh PT.VOKSEL ELECTRIC Tbk (VOKS) pada tahun 2015. Ratarata penghindaran pajak sampel secara keseluruhan sebesar 0,414665 yang berarti rata-rata perusahaan manufaktur dalam penelitian ini membayarkan pajak sebesar 41,46\% dari laba sebelum pajaknya.

Penghindaran pajak yang dimoderasi dengan kepemilikan institusional yang dihitung dengan pengukuran model 1 , hasilnya nilai minimum sebesar -3.981.005.244.000,0000 yang dimiliki oleh PT.KRAKATAU STEEL (PERSERO) Tbk (KRAS) pada tahun 2015 dan nilai maksimum sebesar 2.201.042.379.544,4600 yang dimiliki oleh PT.ASTRA INTERNATIONAL Tbk (ASII) pada tahun 2017. Rata-rata penghindaran pajak yang dimoderasi dengan kepemilikan institusional sampel secara keseluruhan sebesar 76.977.511.205,104660.

Penghindaran pajak yang dimoderasi dengan kepemilikan institusional yang dihitung dengan pengukuran model 2 , hasilnya nilai minimum sebesar $-30,9862$ yang dimiliki oleh PT.UNGGUL INDAH CAHAYA Tbk (UNIC) pada tahun 2015 dan nilai maksimum sebesar 10,6840 yang dimiliki oleh PT.VOKSEL ELECTRIC Tbk (VOKS) pada tahun 2015. Ratarata penghindaran pajak yang dimoderasi 
dengan kepemilikan institusional sampel secara keseluruhan sebesar 0,196801.

Ukuran perusahaan, hasilnya nilai minimum sebesar 25,6199 atau sebesar RP. 133.831.888.816 pada total aset yang dimiliki oleh PT.KEDAUNG INDAH CAN Tbk (KICl) pada tahun 2015 dan nilai maksimum sebesar 33,3202 atau sebesar RP. 295.646.000.000.000 pada total aset yang dimiliki oleh PT.ASTRA INTERNATIONAL Tbk (ASII) pada tahun 2017. Rata-rata ukuran perusahaan sampel secara keseluruhan sebesar 28,889530 yang berarti rata-rata perusahaan manufaktur dalam penelitian ini memiliki total aset sebesar Rp. 14.155.198.583.744.

Umur perusahaan, hasilnya nilai minimum sebesar 1,0000 atau baru melakukan perdagangan sahamnya secara umum pada tahun 2014 yang dimiliki oleh PT.CHITOSE INTERNASIONAL TbK (CINT) dan PT.IMPACK PRATAMA INDUSTRI Tbk (IMPC) dan nilai maksimum sebesar 37,0000 atau sudah melakukan perdagangan saham secara umum selama 37 tahun yang dimiliki oleh PT.TIFICO FIBER INDONESIA Tbk (TFCO) pada tahun 2017. Rata-rata umur perusahaan sampel secara keseluruhan 20,000000 yang berarti rata-rata perusahaan manufaktur dalam penelitian telah menjadi perusahaan go public selama 20 tahun.

Leverage, hasilnya nilai minimum sebesar 0,0941 yang dimiliki oleh PT.TIFICO FIBER INDONESIA Tbk (TFCO) pada tahun 2015 dan nilai maksimum sebesar 5,0733 yang dimiliki oleh PT.ASIA PACIFIC FIBERS Tbk (POLY) pada tahun 2017. Rata-rata leverage sampel secara keseluruhan sebesar 0,519133 yang berarti rata-rata perusahaan manufaktur dalam penelitian ini memiliki proporsi hutang sebesar $51,91 \%$ dari total aset yang dimiliki.

Aliran kas operasi, hasilnya nilai minimum sebesar $-0,1209$ yang dimiliki oleh PT.ERATEX DJAJA Tbk (ERTX) pada tahun 2017 dan nilai maksimum sebesar 0,8839 yang dimiliki oleh PT.INDOCEMENT TUNGGAL PRAKASA Tbk (INTP) pada tahun 2016. Ratarata arus kas operasi sebesar 0,078292 yang berarti rata-rata perusahaan manufaktur dalam penelitian ini memiliki arus kas bersih dari operasi sebesar $7,82 \%$ dari total aset yang dimiliki.

Tabel 2 Hasil Uji Hipotesis

\begin{tabular}{lrrrlrcc}
\hline & Model 1 & \multicolumn{7}{c}{ Model 2 } \\
\hline \multicolumn{1}{c}{ Variabel } & \multicolumn{1}{c}{ B } & \multicolumn{1}{c}{ T } & Sig. & Variabel & B & t & Sig. \\
\hline Konstanta & .143 & 12.821 & .000 & Konstanta & .608 & 7.649 & .000 \\
\hline TA1 & -.009 & -.604 & .546 & TA2 & -.001 & -.157 & .876 \\
\hline TA1*KI & $4.391 \mathrm{E}-$ & .003 & .998 & TA2*KI & .002 & .394 & .694 \\
& 5 & & & & & & \\
\hline SIZE & .023 & 3.279 & .001 & SIZE & -.014 & -5.132 & .000 \\
\hline AGE & .007 & 1.002 & .318 & AGE & -.001 & -2.055 & .041 \\
\hline LEV & .046 & 2.206 & .029 & LEV & -.019 & -2.564 & .011 \\
\hline CFO & .020 & .392 & .696 & CFO & .052 & 1.133 & .259 \\
\hline
\end{tabular}

Sumber: Data diolah

Tabel 2 menunjukan, untuk model 1 hasil uji t yang menghasilkan nilai t hitung, tingkat signifikansi serta koefisien regresi masing- masing variabel. Dengan jumlah data (n) sebanyak 187 dan jumlah variabel (k) sebanyak 
6, dapat dilihat dari tabel distribusi t bahwa nilai t tabel adalah sebesar 1,973.

Didasarkan pada hasil uji statistik $t$, diketahui bahwa t hitung penghindaran pajak adalah sebesar $-0,604$ dengan tingkat signifikansi sebesar 0,546 . Karena nilai t hitung $<$ t tabel $(0,651<1,973)$ dan nilai signifikansi lebih dari 0,05 maka dapat dikatakan bahwa $\mathrm{H}_{0} \mathrm{I}$ diterima dan $\mathrm{Ha1}$ ditolak. Hal ini memiliki arti bahwa penghindaran pajak tidak berpengaruh terhadap biaya hutang, dengan koefisien menunjukkan arah negatif.

Didasarkan pada hasil uji statistik $t$, diketahui bahwa t hitung penghindaran pajak yang dimoderasi dengan kepemilikan institusional adalah sebesar 0,003 dengan tingkat signifikansi sebesar 0,998. Karena nilai $\mathrm{t}$ hitung $<\mathrm{t}$ tabel $(0,003<1,973)$ dan nilai signifikansi lebih dari 0,05 maka dapat dikatakan bahwa $\mathrm{H}_{0} 2$ diterima dan $\mathrm{Ha}_{2}$ ditolak. Hal ini memiliki arti bahwa kepemilikan institusional tidak dapat memoderasi penghindaran pajak terhadap biaya hutang.

Tabel 8 menunjukan, untuk model 2 hasil uji t yang menghasilkan nilai t hitung, tingkat signifikansi serta koefisien regresi masingmasing variabel. Dengan jumlah data (n) sebanyak 186 dan jumlah variabel ( $k$ ) sebanyak 6 , dapat dilihat dari tabel distribusi t bahwa nilai $\mathrm{t}$ tabel adalah sebesar 1,973.

Didasarkan pada hasil uji statistik t, diketahui bahwa t hitung penghindaran pajak adalah sebesar $-0,157$ dengan tingkat signifikansi sebesar 0,876 . Karena nilai t hitung $<$ t tabel $(0,157<1,973)$ dan nilai signifikansi lebih dari 0,05 maka dapat dikatakan bahwa $\mathrm{H}_{0} \mathrm{I}$ diterima dan $\mathrm{Ha1}$ ditolak. Hal ini memiliki arti bahwa penghindaran pajak tidak berpengaruh terhadap biaya hutang, dengan koefisien menunjukkan arah negatif.

Didasarkan pada hasil uji statistik $t$, diketahui bahwa t hitung penghindaran pajak yang dimoderasi dengan kepemilikan institusional adalah sebesar 0,394 dengan tingkat signifikansi sebesar 0,694. Karena nilai t hitung $<$ t tabel $(0,394<1,973)$ dan nilai signifikansi lebih dari 0,05 maka dapat dikatakan bahwa $\mathrm{H}_{0} 2$ diterima dan $\mathrm{Ha} 2$ ditolak. Hal ini memiliki arti bahwa kepemilikan institusional tidak dapat memoderasi penghindaran pajak terhadap biaya hutang.

Didasarkan pada analisis yang telah dilakukan untuk menguji pengaruh penghindaran pajak terhadap biaya hutang menunjukkan hasil dari uji statistik $t$ di dapat koefisien regresi sebesar - 0,009 untuk model 1 dan - 0,001 untuk model 2. Pada model 1 variabel ini menghasilkan nilai t hitung sebesar $-0,604$ dan tingkat signifikansi sebesar 0,546 $(>0,050)$, sementara pada model 2 variabel ini menghasilkan nilai t hitung sebesar $-0,157$ dan tingkat signifikansi 0,876 $(>0,050)$. Dari kedua model yang digunakan dapat dilihat bahwa $\mathrm{H} 1$ ditolak atau dengan kata lain penghindaran pajak tidak berpengaruh terhadap biaya hutang. Nilai koefisien memiliki arah negatif menunjukkan bahwa penghindaran pajak yang dilakukan perusahaan membuat biaya hutang perusahaan semakin turun, namun menurut Astuti dan Aryani (2016) semakin kecil nilai ETR, CETR, dan BTD maka semakin besar perusahaan tersebut dalam penghindaran pajak. Sehingga dapat diartikan di dalam penelitian ini penghindaraan pajak berhubungan positif dengan biaya hutang tetapi tidak signifikan, dengan kata lain penghindaran pajak yang dilakukan perusahaan membuat biaya hutang perusahaan semakin meningkat tetapi tidak signifikan.

Hasil ini berlawanan dengan penelitian yang dilakukan oleh Lim (2011) dan juga penelitian yang dilakukan oleh Kholbaladov (2012), yang menyatakan bahwa penghindaran pajak berpengaruh signifikan negatif terhadap biaya hutang. Penelitian ini juga berlawanan dengan penelitian yang dilakukan oleh Masri dan Martani (2014), serta penelitian yang dilakukan oleh Santosa dan Kurniawan (2016), yang menyatakan bahwa penghindaran pajak berpengaruh signifikan positif terhadap biaya hutang. Namun hasil ini sejalan dengan 
penelitian yang dilakukan oleh Pratama dkk (2017), yang menyatakan bahwa penghindaran pajak berhubungan positif tidak signifikan dengan biaya hutang, sehingga semakin tinggi tingkat penghindaran pajak akan meningkatkan biaya hutang perusahaan tetapi tidak signifikan. Dengan kata lain perusahaan yang melakukan penghindaraan pajak pada saat ini tidak selalu memiliki hutang yang banyak Periode penelitian juga dilakukan setelah pemerintah melakukan reformasi perpajakan dan juga dengan adanya Peraturan Menteri Keuangan No.169/PMK.010/2015 mengenai besaran perbandingan hutang dan modal perusahaan yang telah dikeluarkan pada tahun 2015 yang membuat perusahaan pada saat ini berhati-hati di dalam mengelola hutang. Pada saat ini perusahaan lebih suka melakukan manipulasi transfer pricing dan juga memanfaatkan wilayah tax heaven untuk menghindari pajak.

Didasarkan pada analisis yang telah dilakukan untuk menguji pengaruh moderasi kepemilikan institusional terhadap hubungan penghindaran pajak dan biaya hutang menunjukkan hasil dari uji statistik $t$ didapat koefisien sebesar 0,00004 untuk model 1 dan 0,002 untuk model 2. Pada model 1 variabel ini menghasilkan nilai t hitung sebesar 0,003 dan tingkat signifikansi sebesar 0,998 (>0,050), sementara pada model 2 variabel ini menghasilkan nilai t hitung sebesar 0,394 dan tingkat signifikansi sebesar 0,694 (>0,050). Dari kedua model yang digunakan dapat dilihat bahwa $\mathrm{H} 2$ ditolak atau dengan kata lain kepemilikan institusional tidak dapat memoderasi hubungan penghindaran pajak dan biaya hutang. Jadi, dapat disimpulkan bahwa tingkatan kepemilikan institusional tinggi maupun rendah pada perusahaan-perusahaan manufaktur di Indonesia tidak dapat mempengaruhi hubungan penghindaran pajak dan biaya hutang, dimana hal ini dikarenakan struktur kepemilikan institusional di Indonesia masih berbasis keluarga sehingga kepemilikan dan kontrol menjadi kurang jelas. Hal ini juga menyebabkan fungsi pengawasan terhadap kinerja manajemen menjadi tidak optimal dan fungsi kepemilikan untuk mencegah konflik kepentingan di dalam perusahaan tidak berjalan dengan baik.

Hasil ini berlawanan dengan penelitian yang dilakukan oleh Lim (2011), yang menyatakan bahwa kepemilikan institusional dapat memoderasi hubungan penghindaran pajak dan biaya hutang. Namun hasil ini sejalan dengan penelitian yang dilakukan oleh Kholbaladov (2012), yang menyatakan bahwa kepemilikan institusional tidak dapat memoderasi hubungan penghindaran pajak dan biaya hutang, hal ini dikarenakan investor institusional di Indonesia tidak dapat memberikan pengawasan yang cukup pada tindakan manajemen di dalam kinerja perusahaan dan investor institusional juga tidak dapat mencegah konflik kepentingan yang terjadi antara manajemen dan kreditur karena investor institusional tidak terlalu memperhatikan masalah tersebut.

\section{PENUTUP}

Penelitian ini bertujuan untuk menguji pengaruh penghindaran pajak terhadap biaya hutang dan juga pengaruh moderasi kepemilikan institusional terhadap hubungan penghindaran pajak dan biaya hutang pada perusahaan manufaktur yang terdaftar Bursa Efek Indonesia (BEI) pada tahun 2015, 2016, dan 2017. Pada penelitian ini variabel penghindaran pajak diukur menggunakan dua proksi pengukuran sehingga dibuat 2 model penelitian, dimana pada model 1 penghindaran pajak diukur menggunakan proksi Book Tax Different (BTD) dan pada model 2 penghindaran pajak diukur menggunakan proksi Cash Effective Tax Rate (CETR). Nilai BTD dan CETR berhubungan terbalik dengan penghindaran pajak, dimana semakin besar nilai BTD dan CETR maka semakin kecil penghindaran pajak, begitupun sebaliknya. Penelitian ini menguji sampel sebanyak 191 data pada model 1 dan sebanyak 190 data 
pada model 2 yang didapatkan dari penggunaan purposive sampling. Berdasarkan analisis yang telah dilakukan, diperoleh hasil bahwa (1) penghindaran pajak pada model 1 dan 2 berhubungan positif tidak signifikan terhadap biaya hutang; (2) kepemilikan institusional pada model 1 dan 2 tidak dapat memoderasi hubungan penghindaran pajak dan biaya hutang; (3) Variabel kontrol pada model 1 yaitu ukuran perusahaan dan leverage yang berpengaruh signifikan terhadap biaya hutang, sedangkan umur perusahaan dan arus kas operasi tidak berpengaruh terhadap biaya hutang. Sementara pada model 2 yaitu ukuran perusahaan, umur perusahaan, leverage yang berpengaruh terhadap biaya hutang, sedangkan arus kas operasi tidak berpengaruh signifikan terhadap biaya hutang.
Berdasarkan hasil yang ada di dalam penelitian ini, maka bagi penelitian selanjutnya dapat menggunakan sampel dari sektor perusahaan lain atau dengan seluruh sektor perusahaan yang terdaftar di Bursa Efek Indonesia sehingga hasil penelitian dapat menggenaralisir kondisi ekonomi yang ada. Penelitian selanjutnya juga dapat menggunakan tahun pengamatan yang lebih panjang sehingga hasil penelitian dapat menggeneralisir kondisi ekonomi yang ada. Penelitian selanjutnya serta dapat menambahkan beberapa variabel lain untuk mempengaruhi biaya hutang, seperti corporate governance, kepemilikan manajerial, kepemilikan keluarga, pertumbuhan penjualan dan lain hal sebagainya.

\section{REFERENSI:}

Ashbaugh, H., Collins, DW., LaFond, R. 2004. Corporate Governance and the Cost of Equity Capital, Working Paper, University of Wisconsin.

Ashkhabi, IR., Agustina, L. 2015. Pengaruh Corporate Governance, Struktur Kepemilikan Perusahaan dan Ukuran Perusahaan Terhadap Biaya Utang, Accounting Analysis Journal, 4(3).

Astuti, TP., Aryani, YN. 2016. Tren Penghindaran Pajak Perusahaan Manufaktur di Indonesia yang Terdaftar di BEl Tahun 2001-2014, Jurnal Akuntansi, XX(3), 375-388.

Jensen, MC., Meckling, W. (1976). Theory of The Firm: Managerial Behaviour, Agency Cost, and Capital Structure. Journal of Financial Economics, 11(2), 88-100.

Juniarti., Sentosa, AA. 2009. Pengaruh Good Corporate Governance, Voluntary Disclosure terhadap Biaya Hutang (Cost of Debt), Jurnal Akuntansi dan Keuangan, 11(2), 88-100.

Kholbadalov, U. 2012. The Relationship of Corporate Tax Avoidance, Cost of Debt and Institutional Ownership: Evidence from Malaysia, Atlantic Review of Economics, 2.

Lim, Y. 2011. Tax Avoidance, cost of debt and shareholder activism: Evidence from Korea, Journal of Banking \& Finance, 35, 456-470.

Mardiasmo. 2016. Perpajakan, Yogyakarta: Andi.

Masri, I., dan Martani, D. 2014. Tax Avoidance Behaviour Towards the Cost of Debt, Int. J. Trade and Global Markets, 7(3), 235-249.

Meiriasari, V. 2017. Pengaruh Corporate Governance, Kepemilikan Keluarga, Kepemilikan Institusional, dan Ukuran Perusahaan (Firm Size) Terhadap Biaya Utang, Jurnal IImiah Ekonomi Global Masa Kini, 8(01), 28-34.

Murtianingsih. 2014. Struktur Kepemilikan dan Biaya Ekuitas Pada Perusahaan Manufaktur di Indonesia, Jurnal JIBEKA, 8(2), 39-44.

Pittman, JA., Fortin, S. 2004. Auditor Choice and the Cost of Debt Capital for Newly Public Firms, Journal of Accounting and Economics 37, 113-136. 
Pratama, N., Djaddang, S., Masri, I. 2017. Pengujian Tax Avoidance dan Risiko Kebangkrutan Terhadap Cost of Debt dan Insentif Pajak sebagai Pemoderasi, Konferensi IImiah Akuntansi IV, 2-3 Maret 2017.

Purwanti, N. 2014. Pengaruh Penghindaran Pajak Terhadap Biaya Hutang Pasca Perubahan Tarif Pajak Badan Pada Perusahaan Manufaktur yang Terdaftar di Bursa Efek Indonesia, Jurnal Akuntansi Indonesia, 3(2), 113-128.

Puspita, D., dan Febrianti, M. 2017. Faktor-Faktor yang Memengaruhi Penghindaran Pajak pada Perusahaan Manufaktur di Bursa Efek Indonesia, Jurnal Bisnis dan Akuntansi, Vol 19 No.1, hlm 38-46.

Ross, SA., Westerfield, RW., Jaffe, JF. 2002. Corporate Finance, International Edition, NewYork: McGraw Hill Education.

Ross, SA., Westerfield, RW., Jordan, BD., Lim, J., Tan, R. 2016. Fundamentals ofCorporate Finance, Asian Global Edition, Second edition, NewYork:McGraw Hill Education.

Ross, SA., Westerfield,RW., Jaffe, JF. 2003. Corporate Finance, Sixth Edition, NewYork: McGraw-Hill Primis.

Santosa, JE., Kurniawan, H. (2016). Analisis Pengaruh Tax Avoidance Terhadap Cost of Debt Pada Perusahaan Manufaktur yang Terdaftar di BEI Selama Periode 2010 2014, MODUS, 28(2), 139-154.

Scott, WR. 2012. Financial Accounting Theory, $6^{\text {th }}$ edition, Toronto, Ontario: Pearson Canada Inc.

Suandy, E. 2011. Perencanaan Pajak, Jakarta: Salemba Empat. 
